\title{
PELEMBAGAAN PARTAI POLITIK: STUDI PADA PARTAI SOLIDARITAS INDONESIA KOTA BANDUNG TAHUN 2019
}

\author{
Nanang Suryana ${ }^{1}$, Ari Ganjar Ardiansyah ${ }^{2}$, Firman Manan ${ }^{3}$ \\ ${ }^{1,2,3}$ Universitas Padjajaran, Indonesia \\ 'Email: Nanangsuryana07@gmail.com
}

\begin{abstract}
ABSTRAK
Penelitian ini bertujuan menganalisis proses pelembagaan Partai Solidaritas Indonesia (PSI) Kota Bandung. Penelitian ini didesain dengan menggunakan metode kualitatif. Bertolak dari kerangka teoritik pelembagaan partai politik, penelitian ini menghasilkan beberapa temuan yang berfokus pada empat derajat pelembagaan. Hasil penelitian memperlihatkan derajat kesisteman (systemness) dalam proses pelembagaan di tubuh PSI Kota Bandung masih jauh dari kata ideal. Faktor-faktor seperti penggunaan aturan, prosedur, dan mekanisme yang disepakati dan ditetapkan dalam konstitusi partai belum mampu diterjemahkan PSI Kota Bandung dalam menajemen keorganisasian. Di level derajat identitas nilai (value infusion), PSI Kota Bandung konsisten mengusung nilai yang menjadi landasan partai. Namun, secara prakis beberapa narasi yang diusung partai tidak terlalu mendatangkan insentif secara elektoral. Di level decisional autonomy, kondisi PSI Kota Bandung yang hanya mengandalkan sumber pembiayaan partai dari sumber internal, kendati kondisi ini memberikan keleluasaan dan derajat otonomi suatu partai dalam pembuatan keputusan, namun keterbatasan kemampuan keuangan berdampak pada efektifitas jalannya organisasi. Di level value infusion, narasi dan isu yang dibawa parrtai menjadikan mereka dekat dengan segmen pemilih dari kelompok minoritas, baik dari kelompok keagamaan maupun etnis. Di level keempat (reification), diferensiasi identitas yang dibawa partai nampak belum membumi di tengah publik Kota Bandung.
\end{abstract}

Kata Kunci: Partai Politik; Pelembagaan; PSI.

\begin{abstract}
This study aims to analyze the process of institutionalizing the Indonesian Solidarity Party (PSI) of Bandung. This research was designed using qualitative methods. Departing from the theoretical framework of institutionalizing political parties, this study produced several findings that focused on four degrees of institutionalization. The results showed the degree of systemic (systemness) in the process of institutionalization in the body of PSI Bandung is still far from the ideal word. Factors such as the use of rules, procedures, and mechanisms agreed upon and stipulated in the party's constitution have not been able to be translated into PSI Bandung City in organizational management. At the level of the degree of identity value (value infusion), PSI Bandung consistently carries the values that form the basis of the party. However, in practice some of the narratives carried by the party do not bring electoral incentives too much. At the decisional autonomy level, the condition of PSI in Bandung which only relies on party financing sources from internal sources, although this condition gives the party freedom and degree of autonomy in decision making, but the limited financial capacity has an impact on the effectiveness of the organization's running. At the level of value infusion, the narratives and issues brought by parties make them close to the voter segments of minority groups, both religious and ethnic groups. At the fourth level (reification), the identity differentiation brought by the party does not seem to be down to earth in the city of Bandung.
\end{abstract}

Keywords: Political Parties; Institutionalization; PSI. 


\section{PENDAHULUAN}

Keberadaan partai politik akhir-akhir ini dihadapkan pada kondisi paradoksal. Di satu sisi pilihan atas demokrasi meniscayakan peran serta partai politik di dalamnya. Namun di sisi yang lain, tingkat kepercayaan publik pada partai politik menunjukan tren yang terus menurun. Dua hal yang kontradiktif.

Sekian survei yang dilakukan beberapa tahun kebelakang memperlihatkan tren penurunan kepercayaan publik terhadap partai semakin menguat. Survei Pusat Penelitian Politik (P2P) Lembaga Ilmu Pengetahuan Indonesia (LIPI) pada 19 April-5 Mei 2018 di 34 provinsi menunjukan tingkat kepercayaan publik terhadap demokrasi masih besar. Namun, di sisi yang lain kepercayaan publik terhadap partai politik relatif terpuruk (Cnnindonesia, 2019).

Hal senada juga nampak dari hasil survei yang dilakukan Charta Politika pada 23-26 Agustus 2018. Survei yang dilakukan di 8 kota besar (Medan, Palembang, Jakarta, Bandung, Semarang, Yogyakarta, Surabaya, dan Makassar) menunjukan angka 45,8 persen responden menilai partai politik menjadi lembaga yang tidak bisa dipercaya (Merdeka.com, 2019).

Secara umum, tumbuhnya rasa tidak percaya dan sikap skeptis publik pada partai politik sebagaimana tergambar dalam beberapa survei di atas, dilatarbelakangi beberapa hal. Kasus korupsi yang melibatkan banyak aktivis partai, konflik internal yang gaduh di banyak pemberitaan, performa partai yang masih jauh dari harapan, dan pelembagaan partai yang jalan di tempat adalah beberapa masalah yang masih menghinggapi partai politik di Indonesia sejauh ini (Sinarharapan.com, 2019).

Padahal partai politik dan demokrasi memiliki kaitan yang sangar erat. Tak ada demokrasi tanpa partai politik. Karenanya, derajat kualitas demokrasi, salah satunya ditentukan oleh derajat kualitas partai politik di dalamnya. Kualitas partai politik berelasi kuat dengan proses pelembagaan. Dalam konteks itu, upaya untuk meninjau proses pelembagaan partai politik adalah bagian dari upaya memastikan demokrasi diisi oleh partai politik yang berkualitas (Randall dan Lars, 2002).

Menurut Huntington (Pamungkas, 2011), pelembagaan adalah proses dimana organisasi dengan mana tata cara (prosedur) memperoleh nilai baku dan stabil. Atau dalam pengertian Randall dan Lars (2002), pelembagaan diartikan sebagai proses dimana partai menjadi stabil (mantap) dalam hal pola perilaku yang terintegrasi maupun dalam hal sikap (attitude) dan budaya.

Randall dan Lars (2002) merumuskan 4 dimensi yang dapat dijadikan pisau analisis proses pelembagaan partai politik: dimensi kesisteman, dimensi identitas nilai, dimensi otonomi dan dimensi citra publik. Pertama, dimensi kesisteman, dimensi ini merupakan persilangan dari aspek internal dan struktural. Dalam dimensi ini dijelaskan mengenai fungsi-fungsi partai politik (fungsi sosialisasi politik, rekruitmen politik, partisispasi politik, pemadu kepentingan, komunikasi politik, pengendalian konflik dan kontrol politik).

Kedua, dimensi identitas nilai (value infusion) merupakan hasil dari persilangan aspek internal dengan kultural, dimensi ini berkaitan dengan identitas partai politik yang berdasarkan ideologi partai. indikator dari dimensi ini adalah hubungan partai politik berkaitan dengan kelompok tertentu, dalam hal ini ketergantungan partai politik dengan kelompok sosial tertentu. Kemudian pengaruh klientisme dalam organisasi dimana dalam hubungan antara partai dengan anggota bersifat instrumentalis (didasarkan pada materi) atau bersifat ideologis (berdasarkan ideologi yang diterapkan oleh partai politik).

Ketiga, dimensi otonomi suatu partai dalam pembuatan keputusan (decisional

Nanang Suryana, Ari Ganjar Ardiansyah, Firman Manan, Pelembagaan Partai Politik: Studi Pada Partai Solidaritas Indonesia Kota Bandung Tahun 2019 
autonomy), sebagai hasil persilangan aspek eksternal dengan struktural. Indikator terciptanya dimensi otonomi adalah dalam pembuatan keputusan oleh partai poltik berkaitan dengan hubungan partai dengan aktor luar partai, dalam hal ini pengusaha, pemerintah, ormas, dll. Hubungan partai dengan pihak luar ini bersifat saling ketergantungan atau ada salah satu pihak yang mendominasi.

Keempat, dimensi citra publik (reification) terhadap suatu partai politik sebagai persilangan aspek eksternal dengan kultur. Indikator dari dimensi pengetahuan publik tentang partai politik adalah pada keberadaan partai politik yang ada di tengah publik sudah melekat pada pengetahuan masyarakat ataukah masyarakat belum mengetahui partai politik tersebut.

Fakta melemahnya pelembagaan partai politik secara khusus, dan sistem kepartaian secara umum, dinilai menjadi salah satu penyebab rendahnya daya survivalitas banyak partai politik. Sebagaimana yang dikatakan Huntington, dalam konteks pembangunan politik, yang terpenting bukanlahjumlah partaipoltikyang ada, melainkan sejauh mana kekokohan dan adaptabilitas partai dalam sistem kepartaian yang berlangsung (Huntington, 1968).

Di Indonesia paska orde baru, sistem politik sudah tidak lagi bekerja sebagai non-party system. Partai politik telah demikian omnipotent dan omnipresent dalam kehidupan politik. Tidak ada satu pun wilayah politik yang luput dari keterlibatan parpol di dalamnya (Ahmad, 2009).

Tanda dari surplusnya kebebasan politik ditandai dengan kelahiran partaipartai politik baru. Terlebih mejelang banyak momen elektoral. Hampir bisa dipastikan, partai politik baru tersebut selalu datang dengan gagasan menjadi antitesa dari partaipartai lama yang dianggap gagal melakukan fungsi-fungsi intermediary. Namun, secara praksis, hanya sedikit dari partai-partai baru yang memiliki daya survivalitas sehingga dapat bertahan dalam momen-momen berikutnya (Romli, 2008).

Bertolak dari latar belakang di atas, peneliti tertarik melihat proses pelembagaan sebuah partai politik baru bernama Partai Solidaritas Indonesia (PSI). PSI tampil dengan diferensiasi identitas yang tinggi ke tengah publik. Dalam banyak kasus, mereka bahkan secara aktif menyerang partaipartai yang dianggap tidak sesuai dengan platform partai nasionalis. Karenanya, menjadi menarik untuk melihat proses pelembagaan di internal PSI Kota Bandung guna memastikan narasi yang mereka bawa bukan hanya berupa resonansi yang hampa, namun berangkat dari sebuah partai politik yang kuat.

Isu pelembagaan masih menjadi isu sentral dalam studi kepartaian. Selain karena posisi partai politik yang begitu vital dalam demokrasi, isu pelembagaan selalu relevan karena banyak studi yang memperlihatkan justru demokrasi tidak berjalan internal partai. Oleh karena itu, isu pelembagaan akan terus relevan selama kepercayaan pembenahan pada institusi demokrasi semacam partai politik akan berkorelasi dengan peningkatan kualitas demokrasi (Amalia, 2013).

Pelembagaan partai politik adalah proses pemantapan partai politik baik dalam wujud perilaku yang memola maupun dalam sikap atau budaya, sehingga partai politik menjadi lebih dari sekedar organisasi. Pelembagaan partai politik mengandung dua dimensi: internaleksternal dan struktural-attitudinal. Dari kombinasi kedua dimensi ini dihasilkan empat faktor yang dapat digunakan untuk menganalisis proses pelembagaan sebuah partai politik, yaitu: derajat kesisteman (systemness), derajat identitas nilai (value infusion), derajat otonomi suatu partai dalam pembuatan keputusan (decisional autonomy), dan derajat pengetahuan publik (reification) terhadap suatu partai politik (Anggara, 2013). 


\section{METODE}

Penelitian ini menggunakan metode kualitatif. Proses dimulai dengan memilih topik penelitian, merumuskan pertanyaan penelitian, menyusun rancangan penelitian, mengumpulkan data, menganalisis data/ temuan penelitian, menginterpretasi data/temuan penelitian, dan di akhir menyusun laporan penelitian. Lebih lanjut Moleong (2007) metode kualitatif bersifat deskriptif, lebih mementingkan proses dari pada hasil, membatasi studi dengan fokus, memiliki seperangkat kriteria untuk memeriksa keabsahan data, dan rancangan penelitiannya bersifat sementara serta hasil penelitiannya disepakati oleh kedua belah pihak antara peneliti dan subjek penelitian.

Pemilihan metode kualitatif dalam penelitian ini karena peneliti menilai metode kualitatif sesuai dengan tujuaj penelitian dalam menjawab rumusan masalah yang diajukan. Upaya tersebut hemat peneliti membutuhkan perangkat motodologis yang disediakan metode kualitatif. Oleh karena itu, sebagaimana umumnya penelitian kualtitatif, penelitian ini melakukan analisis data secara induktif dimana peneliti berusaha membangun pola-pola, kategori-kategori, dengan teknik mengolah data ke dalam unit-unit informasi yang lebih abstrak, mengembangkan konstruksi (beragam pemaknaan), dan interpretasi atas apa yang peneliti lihat, dengar, dan pahami.

Sumber data salam penelitian ini adalah subyek dari mana data dapat diperoleh (Arikunto, 2006). Sumber data primer, yaitu data yang langsung dikumpulkan oleh peneliti dari sumber pertamanya (Suryabrata, 1987). Sumber data primer dalam penelitian ini adalah Partai Solidaritas Indonesia Kota Bandung sumber data sekunder, yaitu data yang langsung dikumpulkan oleh peneliti sebagai penunjang dari sumber pertama. Dapat juga dikatakan data yang tersusun dalam bentuk dokumen-dokumen (Suryabrata, 1987).

\section{HASIL DAN PEMBAHASAN}

Pelembagaan atau institusionalisasi partai politik yang juga dipahami sebagai kondisi multi dimensi sebagaimana yang dikemukakan oleh Randall dan Svansand, termasuk Basedau dan Stroth yang mendefinisikan pelembagaan atau institusionalisasi partai politik merupakan sistesis dari berbagai aspek meliputi aspek internal-eksternal; dan aspek struktural nilainilai, yang meliputi: (1) Derajat kesisteman, (2) Value infusion, (3) Otonomi, dan (4) Reification (Firman, 2019).

\section{Level Systemness}

Pada level systemness, PSI Kota Bandung belum menjalankan roda organsiasi secara prosedural belum sesuai dengan aturan, prosedur, dan mekanisme yang telah disepakati dan ditetapkan dalam Anggaran Dasar(AD) dan Anggaran Rumah Tangga (ART) secara konsisten. Kondisi ini misalnya dapat dilacak dari kesesuaian antara apa yang tertulis dalam dokumen AD-ART partai, dengan kenyataan praktik pengelolaan partai secara praktis.

Masih nampak ketidaksesuaian sistem kaderisasi sebagaimana yang tertulis di AD-ART dan kenyataan praktik kaderisasi di internal partai. Dalam ADART, khususnya Bab V (Sistem Kaderisasi), tertulis dalam Pasal 12 ayat 1 tentang Bentuk dan Sumber PSI bahwa PSI adalah Partai Kader. Sumber kader partai diantaranya diperoleh dari: a) Kader yang tersebar di sayap-sayap partai; b) Individu yang telah melalui jejaring kaderisasi, c) Individu yang dianggap Dewan Pembina satu visi dan misi dengan PSI. Dalam Bab yang sama, pada pasal 13 tentang Jenjang Perkaderan, disebutkan jenis dan tingkatan kader yang didasarkan pada proses kaderisasi internal di setiap tingkatan.

Fakta di lapangan, peneliti menemukan sistem kaderisasi yang tertulis dalam dokumen AD-ART belum tercermin dalam proses kaderisasi di tubuh PSI Kota Bandung. Pemilahan jenis kader yang didasarkan 
jenjang kaderisasi dan sumber kader yang tersebar di sayap-sayap partai hampir tidak berjalan. Bahkan, nampak jelas basis kaderisasi di PSI Kota Bandung mayoritas bersumber dari pendaftar caleg yang akan maju pada Pileg 2019.

Dengan kata lain, rekruitmen kader PSI Kota Bandung belum didasarkan jenjang proses kaderisasi yang sistematis, namun bergantung pada momentum elektoral seperti Pileg yang secara inheren mensyaratkan para bakal calon anggota legislatif yang akan maju dalam palagan Pileg 2019 merupakan kader partai. Di luar itu, kader-kader PSI adalah mereka yang tergabung dalam struktur pengurus kecamatan dimana secara jumlah hanya sedikit karena terdiri dari tiga struktur inti di masing-masing pengurus kecamatan, yakni ketua, sekretaris, dan bendahara.

Padahal rekrutmen politik memegang peranan penting dalam sistem politik suatu negara. Sebab, proses ini menentukan orangorang yang akan menjalankan fungsi-fungsi sistem politik negara melalui lembagalembaga politik yang ada.54 Rekrutmen politik secara khusus sering merujuk pada seleksi kandidat (kandidasi), rekrutmen legislatif dan eksekutif (Lewis, 2002).

Namun, kendati secara umum jalannya proses kaderisasi kenggotaan partai belum mencerminkan amanat konstitusi organisasi, beberapa temuan lain memperlihatkan kondisi yang sedikit menjajikan. Hal ini misalnya dapat dilacak melalui pola rekrutmen yang mereka gunakan.

Pola rekrutmen kaderisasi PSI yang sesuai dengan AD-ART partai yakni komitmen mereka pada pembatasan usia di bawah 45 tahun, tidak boleh pernah aktif di partai lain, dan merupakan orang baik dalam artian tidak pernah terlibat masalah kriminalitas. Sebagai partai politik yang berusaha menawarkan kebaruan, komitmen pada hal-hal tersebut hemat peneliti patut mendapat apresiasi, terlebih di tengah pragmatisme banyak partai politi lain yang hanya berorientasi pada jumlah kader, tanpa memberikan porsi pada nilai dan syarat-syarat lain yang sesuai dengan platform partai.

Kaderisasi adalah jantung partai politik. Proses kaderisasi bukan hanya berkaitan dengan kelangsungan partai politik sebagai sebuah entitas semata, melebihi itu, kaderisasi juga bertalian erat dengan manifestasi visi-misi ataupun gagasan besar yang diusung partai politik. Di mana, narasi besar itu akan menjadi sumber inspirasi yang mampu menjadi penggerak moral dan sumber ideologis dari setiap arah dan gerak kader (Marsh, 2011). Dengan kata lain, kaderisasi merupakan instrumen untuk melahirkan ataupun merekrut kader yang dalam setiap geraknya diharapkan mampu merepresentasikan gagasan-gagasan yang dibawa oleh partai dan berkesesuain dengan apa yang menjadi visi besar partai politik (Joseph,1984).

Temuan lain dalam penelitian ini, peneliti melihat keterkaitan proses pengambilan keputusan yang dalam ADART PSI diatur dalam BAB XII tentang Permusyawaratan, khususnya sebagaimana yang tertuang dalam pasal 23 tentang jenisjenis permusyawaratan partai di tingkat daerah disebutkan ada tiga jenis: sidang paripurna daerah, rapat harian daerah, dan rapat komite kerja belum termanifestasikan secara praksis dalam jalannya roda organisasi.

Bertolak dari hasil pengamatan dan wawancara peneliti terhadap beberapa narasumber, peneliti mendapati kenyataan jenis-jenis permusyawaratan sebagaimana diatur dalam AD-ART masih jarang dilaksanakan, atau bahkan nyaris tidak pernah. Hal ini misalnya tercermin jelas dalam proses pergantian kepemimpinan dalam tubuh PSI yang tidak dilakukan dalam sebuah forum pengambilan keputusan secara formal, namun dilakukan secara informal.

Temuan penelitian selanjutnya yang berkait dengan derajat kesisteman, yakni 
soal origins atau asal-usul partai politik. Seperti yang sudah disinggung sebelumnya, analisis soal origins akan berkaitan dengan asal-usul terbentuknya sebuah partai politik, apakah partai tersebut bentukan elit (atas) atau lahir dari kehendak massa (bawah).

Secara umum dapat dikatakan PSI terbentuk dari kalangan bawah (massa). Mengingat latar belakang kelahiran PSI di banyak daerah diinisiasi oleh banyak anak muda yang kecewa terhadap partai politik lama. Hal ini bisa dilihat sebagaimana yang tertuang dalam AD-ART PSI sendiri yang mengharuskan kader-kadernya adalah orang-orang baru yang sebelumnya tidak pernah tergabung secara struktural partai politik lama.

Bahkan secara tegas dalam banyak pernyataan politik di ragam media, sikap ini dipilih PSI karena tidak ingin tersandera dengan kepentingan politik lama, seperti praktik klientelisme, rekam jejak yang buruk, dan beban sejarah dan citra yang buruk terhadap partai politik lama. Berangkat dari fakta tersebut, nampak PSI sebagai sebuah partai politik baru memang terbentuk dari bawah, bukan dari kalangan elit politik yang sudah ada sejak lama.

Namun, kendati PSI mendaku sebagai partai politik baru yang tumbuh dari bawah dan bukan bentukan elit politik, kehadiran sosok Jeffrie Geovanie selaku Ketua Dewan Pembina DPP PSI seolah mematahkan dalil PSI sebagai partai yang terbentuk dari bawah. Sebagaimana diketahui, Jeffrie Geovanie pernah tercatat duduk menjadi elit di beberapa partai. Jeffrie tercatat pernah menjadi bagian dari Partai Amanat Nasional (PAN), Partai Golongan Karya (Golkar), dan Partai Nasional Demokrat (Nasdem). Kehadiran Jeffrie inilah yang banyak memunculkan tanda tanya terkait indepedensi PSI dari jaringan elit partai yang sudah ada lama dalam praksis politik di Indonesia. Sehingga, tidak sedikit yang menganilisis
PSI merupakan bagian dari eksperimentasi politik Jeffrie Geovanie di ceruk pemilih nasionalis. Namun, karena hal tersebut tidak menjadi fokus dari penelitian ini, peneliti tidak mengelaborasi lebih juah dan lebih berfokus pada PSI Kota Bandung sebagai subjek dalam penelitian ini.

\section{Level Value infusion}

Derajat identitas nilai berkaitan dengan: a) hubungan partai politik dengan kelas populis tertentu (popular base), hal ini berkaitan dengan pertanyaan apakah suatu partai politik mengandung dimensi sebagai gerakan sosial yang didukung oleh kelompok populis tertentu, seperti buruh, petani, kalangan masyarakat tertentu, komunitas agama tertentu, komunitas kelompok etnik tertentu, b) pengaruh klientelisme dalam organisasi, dengan: a) hubungan partai politik dengan kelas populis tertentu (popular base), hal ini berkaitan dengan pertanyaan apakah hubungan partai dengan anggota cenderung bersifat instrumentalis (anggota selalu mengharapkan tangible resources berupa materi dari partai) ataukah lebih bersifat ideologis (anggota mengenal dan mengharapkan partai bertindak berdasarkan identifikasi terhadap ideologi partai). Partai politik yang mempunyai basis sosial pendukung yang spesifik niscaya akan memiliki identitas nilai yang jelas (Bakry dan Andy, 2009).

Suatu partai politik dapat dikatakan telah melembaga dari segi identitas nilai apabila partai tersebut telah memiliki lapisan sosial atau golongan masyarakat sebagai pendukung loyal (basis sosial) karena pola dan arah kebijakan yang diperjuangkannya dan apabila dukungan yang diberikan kepada partai itu bukan semata-mata karena menerima materi tertentu dari partai melainkan karena orientasi politiknya sesuai dengan ideologi atau platform partai tersebut. Sebagai catatan tambahan, partai politik yang mempunyai basis sosial pendukung yang 
spesifik niscaya akan memiliki identitas nilai yang jelas (Budiardjo, 1985).

PSI di Kota Bandung, sebagaimana yang juga tercermin pada PSI pusat, memiliki kedekatan dengan kelompok populis tertentu, baik dengan kelompok berlatar belakang agama juga etnis tertentu. Hal ini dapat dipahami mengingat platform dan narasi yang diusung PSI bernafaskan inkulsivitas. Utamanya terhadap kelompokkeompok yang selama yang ini dianggap banyak tersisihkan dari politik.

Identitas nilai sebagai partai nasionalis menjadikan PSI memiliki kedekatan dalam konteks identifikasi partai dengan PDIP. Hal ini dikonfirmasi oleh Ketua DPD PSI Kota Bandung. Oleh karennya, dapat dikatakan, segmen pemilih dan konstituen PSI berada pada "kolam" yang sama dengan PDIP. Namun, PSI secara spesifik menentukan titik bidik konstituennya pada segmen pemilih pendukung isu anti intoleransi, yang sebagian besar, berasal dari kelompok masyarakat minoritas.

Di level ini, PSI harus tetap mendapat apresiasi, terlebih lagi untuk ukuran sebuah partai politik baru. Boleh dikatakan PSI Kota Bandung menunjukan sebuah kemajuan. Terlebih lagi, mengingat dari berbagai studi, di Indonesia secara umumnya masih sukar menemukan partai politik dengan basis sosial yang spesifik. Hal tersebut dikarenakan ideologi partai belum dijabarkan dalam bentuk pola dan arah kebijakan pubik yang jelas, sehingga perbedaan diantara partai politik tersebut baru tampak secara simbolik semata. Bukan berdasar pada platform kebijakan partai yang spesifik terhadap isu-isu tertentu.

\section{Level Decisional autonomy}

Dimensi otonomi suatu partai dalam pembuatan keputusan berkaitan dengan hubungan partai politik dengan aktor di luar partai politik, baik dengan sumber otoritas tertentu (penguasa, pemerintah), maupun dengan sumber dana (pengusaha, penguasa, negara atau lembaga luar) dan sumber dukungan massa (organisasi masyarakat): (a) apakah partai tergantung kepada aktor luar tersebut ataukah hubungan itu bersifat saling tergantung (interdependen), dan (b) apakah keputusan paitai ditentukan oleh aktor luar ataukah hubungan itu berupa jaringan (linkage) yang memberi dukungan kepada partai (Firman, 2017).

Kendala keuangan adalah masalah lain yang dihadapi PSI Kota Bandung. Berbeda dengan partai-partai lama yang lebih mapan, akses keuangan PSI Kota Bandung relatif hanya mengandalkan iuran anggota dan sumbangan yang sifatnya masih terbatas. Kondisi ini di satu sisi berdampak positif pada otonomi pengambilan keputusan di internal partai yang masih relatif demokratis. Berbeda dengan proses pengambilan keputusan di partai-partai lama yang bepusat pada ketua umum, di internal PSI, relatif proses pengambilan keputusan partai tidak dimonopoli oleh pucuk pimpinan(Gaffar, 2000).

Sebagai contoh, pada saat pengundian nomor urut caleg, PSI Kota Bandung melakukan pengundian secara transparan. Setelahnya, nama-nama yang telah memiliki nomor urut tersebut diserahkan kepada DPW dan DPP untuk disahkan. Namun, pada sisi yang lain, keterbatasan sumberdaya keuangan semacam ini berdampak pada jalannya roda organisasi. Bahkan, guna memenuhi kebutuhan dasar seperti ketersediaan seketariat pun, PSI Kota Bandung memiliki keterbatasan. Ditambah, kemampuan pengurus dalam mengakses sumber-sumber pendaan partai dari pihak lain juga relatif terbatas.

\section{Level Reification}

Derajat pengetahuan publik (reification) terhadap suatu partai politik berkaitan dengan pengetahuan publik pada partai politik, merujuk pada pertanyaan apakah keberadaan partai politik tersebut telah tertanam pada imajinasi publik. Bila keberadaan partai politik tertentu telah tertanam pada imajinasi publik, maka pihak lain baik para individu maupun 
lembaga akan menyesuaikan aspirasi dan harapan ataupun sikap dan perilaku mereka dengan keberadaan partai politik tersebut. Derajat pengetahuan publik ini merupakan fungsi dari waktu dan kiprah partai tersebut (Hanafi, 2018).

Secara praktis, dibanding dengan beberapa partai politik baru lainnya, terkecuali Perindo yang secara massif memanfaatkan fasilitas iklan di televisi, popularitas PSI terbilang relatif cukup baik. Hal ini misalnya tercermin dari temuan beberapa survei popularitas partai politik yang dilakukan setidaknya sejak tahun 2017. Namun, dalam perkembangannya menjelang Pileg 2019, berdasar pada temuantemuan survei, peningkatan tingkat pengenalan PSI di tengah pemilih kurang menjanjikan. Hal ini terbukti kemudian pada hasil Pileg 2019 dimana PSI tidak mampu untuk lolos ambang batas raihan suara parlemen sebesar empat persen.

PSI sendiri tergolong partai politik yang maksimal menggunakan saluransaluran komunikasi politik maupun komunikasi persuasif, pun juga PSI Kota Bandung. PSI Kota Bandung melakukan komunikasi massa, seperti melalui radio, maupun menulis kolom-kolom opini dalam media sosial. PSI Kota Bandung aktif melakukan komunikasi interpersonal, hal itu dibuktikan dengan bagaimana mereka yang selain sering mengadakan pertemuanpertemuan dengan berbagai macam tokoh, mereka pun aktif mengadakan dialogdialog ataupun membuka ruang-ruang diskusi.

Selain itu, PSI Kota Bandung aktif dalam melakukan konsolidasi dalam tubuh partai, yang tujuannya selain penguatan secara internal, juga untuk mengusahakan secara maksimal komunikasi politik kepada publik (dalam hal ini pubik Kota Bandung) agar lebih terorganisir dan sistematis, tentu saja guna meningkatkan pengetahuan publik Kota Bandung terhadap PSI. Untuk itu, mereka pun aktif melakukan komunikasi organisasi.
Dengan kata lain, PSI Kota Bandung pun secara aktif menggunakan dua metode kampanye, yakni kampanye modern dan kampanye tradisional. Kampanye modern adalah metode kampanye dengan menggunakan instrumen-instrumen, seperti media radio dan sebagainya. Sementara kampanye tradisional adalah metode kampanye dengan tatap muka secara langsung.

Menurut Norris, salah seorang ilmuwan komunikasi yang menganut pendekatan modernisasi, di kebanyakan negara, bahkan di negara demokrasi maju sekalipun, munculnya format kampanye modern yang bertumpu pada media radio serta model kampanye pasca modern dengan merambah new media, sepeti internet, tidaklah membuat format dan gaya kampanye tradisional yang bertumpu pada pembangunan jaringan sosial kandidat, berbasis sukarelawan atau aktivis partai serta komunikasi langsung (face to face communication) antara kandidat dan pemilih menjadi hilang. Yang terjadi adalah, model kampanye gaya lama tersebut disempurnakan atau dilengkapi (supplemented) secara substansial oleh model-model kampanye gaya baru.

Diakui, kecenderungan fenomena pembaruan ini menjadi kecenderungan umum negara-negara berkembang. Sebagai tambahan, Norris pun mencatat bahwa fenomena tersebut terjadi juga di negara-negara makmur atau negara di mana peran mesin partai masih kuat (Labolo dan Ilham, 2015). Kampanye tradisional pun masih hidup karena adanya partai-partai kecil yang memiliki sumber dana terbatas untuk berkampanye di media. Dengan demikian, dapat dikatakan meski dengan sumber dana yang operasional yang terbatas, PSI Kota Bandung sudah berusaha semaksimal mungkin untuk meningkatkan reifikasi atau derajat pengetahuan publik, dengan tidak hanya mengandalkan format kampanye tradisional, tetapi juga format kampanye modern. 
Kondisi demikian sudah selayaknya dibenahi, terlebih, mengacu pada salah satu prinsip politik PSI yang ditujukan menjadi partai modern, masalah mendasar seperti ini seharusnya bukan lagi menjadi sebuah hambatan. Gagasan menjadikan PSI menjadi partai dengan nilai-nilai terbuka, demokratis, terpimpin, berbasis platform, budaya partisipasi dan berkemajuan, harus didahului oleh pembenahan manajemen organsisasi. Mengingat, hal yang substantif sukar digapai jika hal-hal teknis tidak diselesaikan terlebih dahulu. Bila diringkas, semua itu mengarah kepada profesionalitas dan cara kerja dan manajemen organisasi yang sistematis dalam tubuh organisasi (Nurhasim, 2013).

Di sisi yang lain, berdasar pada hasil penelitian di lapangan, pengenalan publik pada PSI lebih dilatari oleh beberapa isu kontroversial yang bahkan menjadi platform PSI itu sendiri. Hal ini menjadikan pengenalan publik pada PSI Kota Bandung lebih berdimensi negatif secara citra.

Hal ini misalnya disebabkan oleh beberapa narasi politik yang diamplifikasi DPP PSI yang cukup merepotkan gerak partai di daerah, termasuk di Kota Bandung. Kondisi ini diamini secara eksplisit oleh Ketua DPD PSI Kota Bandung. Sebagai contoh, narasi PSI yang menolak perda berbasis agama dan partai anti poligami, turut membentuk citra PSI sebagai partai yang mengeliminasi wacana agama, sebuah citra yang kurang popular di tengah mayoritas pemilih. Kondisi ini diperkuat misalnya dengan pengalaman adanya pengusiran terhadap salah satu caleg yang berkampanye di Dapil 6 Kota Bandung karena alasan tersebut. Fenomena ini cukup memberi gambaran tumbuhnya resistensi terhadap PSI dan nilai yang dibawanya di tengah pemilih.

\section{SIMPULAN}

Penelitian ini berkesimpulan proses pelembagaan di tubuh PSI Kota Bandung masih berjalan dinamis. Sebagai partai politik baru yang berusaha menawarkan gagasan menjadi antitesa dari partai politik lama, PSI Kota Bandung belum menunjukan performa yang terlalu menjanjikan.

Segudang masalah pelembagaan masih menyandera PSI Kota Bandung. Perbaikan dan penguatan institusi bisa dilakukan dimulai dari hal-hal mendasar dalam manajemen organisasi, seperti: distribusi kewenangan, pembagian tugas, peningkatan kuantitas dan kualitas sumber daya manusia, penguatan sumberdaya keuangan partai, ketersediaan secretariat permanen, pola kaderisasi yang sistematis, dan distribusi kader di kanal-kanal pemilih yang menjadi target utama PSI.

Sebelum beranjak menjadi partai politik yang kuat secara politik, PSI Kota Bandung harus terlebih dahulu menjadi partai politik yang kuat secara manajerial. Jika tidak, narasi dan gagasan besar yang diusung tidak akan memiliki pijakan yang kuat. Terlebih dalam dinamika elektoral yang kian dinamis, penguatan infrastuktur partai adalah modal dasar yang harus dimiliki oleh semua partai politik.

Di level citra, PSI Kota Bandung harus mempu membumikan narasi dan gagasan besar yang diusung DPP PSI sehingga compatible dengan frekuensi publik Kota Bandung. Jika tidak, ceruk pemilih PSI Kota Bandung tidak akan meluas dan tentu akan berdampak pada eksistensi dan survivalitas PSI Kota Bandung.

Dengan modal keterpilihan tiga kader PSI Kota Bandung di DPRD Kota Bandung seharusnya dapat menjadi modal kuat bagi penguatan partai kedepan. Setidaknya, aspek pembiayaan partai dan jejaring yang dimiliki dapat berkontribusi bagi penguatan kelembagaan partai kedepan.

\section{DAFTAR PUSTAKA}

Ahmad, D. (2009). Iklan Politik TV, Modernisasi Kampanye Politik Pasca 
Orde Baru. Yogyakarta: LKis.

Amalia, L. S.. (2013). Evaluasi Sistem Kepartaian di Era Reformasi. Jurnal Penelitian Politik LIPI, 10 (2) 145-161. Anggara, Sahya. (2013). Sistem Politik Indonesia. Bandung: CV Setia Pustaka.

Arikunto, S. (2006). Prosedur Penelitian: Suatu Pendekatan Praktik. Jakarta: PT. Rineka Cipta.

Bakry, La dan Andy Ramses M. (editor). (2009). Politik dan Pemerintahan Indonesia. Jakarta: MIPI.

Budiardjo, Miriam. (1985). Dasar Dasar Ilmu Politik. Jakarta: Gramedia.

Agung, Bintoro. (2018). Survei LIPI: Demokrasi Kian Dipercaya, Parpol Makin Dijauhi. (online). https:// www.cnnindonesia.com/nasional/ 20180720025810-32-315566/surveilipi-demokrasi-kian-dipercayaparpol-makin-dijauhi diakses tanggal 19 juli 2019.

Creswell, J., W. (2012). Research Design Pendekatan Kualitatif, Kuantitatif dan Mixed; Cetakan ke-2. Yogyakarta: Pustaka Pelajar.

Firman, Noor. (2017). Evaluasi Kondisi Kepartaian 14 Tahun Reformasi Dalam Perspektif Pelembagaan Sistem Kepartaian. Jurnal Masyarakat Indonesia, 38 (2), 221-250. (2019). Institusionalisasi Parpol Menyambut Pemilu 2019, diakses darihttps://www.slideshare.net/ doelha/institusionalisasi-partaipolitik-menyambut-pemilu-2019? from action=save, 20 Desember 2019. Gaffar, Afan. (2000). Politik Indonesia, Transisi Menuju Demokrasi. Pustaka Pelajar: Yogyakarta.

Hanafi, Ridho Imawan. (2018). Kemunculan Dan Tantangan Partai Politik Baru Pada Pemilu 2019, Jurnal Penelitian Politik LIPI, 15(2), 197-213.

Huntington, S. (1968). Political Order in Changing Societies, New Haven: Yel University Press
Joseph A. (1984). On the Theory of Party Organization. The Journal of Politics, $46(2,369-400$.

Labolo, M dan Ilham, T. (2015). Partai Politik dan Sistem pemilihan Umum di Indonesia: Teori, Konsep dan lsu Strategis. Jakarta: Raja Grafindo Persada.

Lewis-Beck, Michael dan Chlarson, Kevin. (2002). Party, Ideology, and Institution in 1995 French Presidential Election. The British. Journal of Political Science, 32 (3), 489-512.

Marsh, David., dan Stoker, Gary. (2011). Teori dan Metode Dalam Ilmu Politik. Bandung: Nusa Media.

Moleong, L. J. (2007). Metode Penelitian Kualitatif. Bandung: PT. Remaja Rosdakarya.

Nurhasim, M. (2013). Kegagalan Modernisasi Partai Politik di Era Reformasi. Jurnal Penelitian Politik, 10 (1), 17-28.

Pamungkas, Sigit. (2011). Partai Politik: Teoridan Praktik di Indonesia. Yogyakarta: Institute for Democracy and Welfarism

Priyasmoro, M. Radityo. (2018). Survei Charta Politika: Kepercayaan publik terhadap parpol masih rendah. (online) https://www.merdeka. $\mathrm{com} /$ politik/survei-charta-politikakepercayaan-publik-terhadapparpol-masih-rendah.html, diakses 22 Juli 2019

Randall, Vicky dan Lars, Svasand. (2002). Party Institutionalisation in New Democracies. Party Politics, 34 (1)

Romli, Lili, dkk. (2008). Kerangka Penguatan Partai Politik di Indonesia. Jakarta: Puskapol Fisip UI.

Sinar Harapan. (2018). LSI: Kepercayaan Masyarakat ke Parpol A n j 1 o k . (online) http://www.sinarharapan. co/hukumdanpolitik/read/3962/lsi kepercayaan_masyarakat_ke_parpol_ anjlok, diakses 22 Juli 2019

Suryabrata, S. (1987). Metode Penelitian. Jakarta: Rajawali. 